\title{
Improvement of Lower Secondary Arabic Language Teaching and Learning through the Implementation of Classroom-Based Assessments (PBD)
}

\author{
Hafilah Abd Satar, Nik Mohd Rahimi Nik Yusoff \\ Universiti Kebangsaan Malaysia, Bangi, Selangor, Malaysia \\ Email: ummubalqis1973@gmail.com
}

How to cite this paper: Satar, H. A., \& Yusoff, N. M. R. N. (2019). Improvement of Lower Secondary Arabic Language Teaching and Learning through the Implementation of Classroom-Based Assessments (PBD). Creative Education, 10, 2555-2563. https://doi.org/10.4236/ce.2019.1012183

Received: October 16, 2019

Accepted: November 24, 2019

Published: November 27, 2019

Copyright $\odot 2019$ by author(s) and Scientific Research Publishing Inc. This work is licensed under the Creative Commons Attribution International License (CC BY 4.0).

http://creativecommons.org/licenses/by/4.0/

\section{c) (i) Open Access}

\begin{abstract}
Classroom-based assessment is a continuous process in teaching and learning to gain information about students' mastery and the effectiveness of teachers' pedagogy. This study reports on the improvement of Arabic language teaching and learning through the implementation of classroom-based assessment which was conducted correctly and effectively in the classroom. This study is a case study using a qualitative approach. The data was obtained through interviews and document analysis of three lower secondary Arabic language teachers, who are also national level main coaches for classroom-based assessment. Selection of interview participants was done through purposive sampling. Interview transcript data were first referred to the study participants and then analysed using the Nvivo software 12 . The findings proved that the implementation of a holistic and continuous classroom-based assessment of Arabic language can enhance student achievement in four key language skills namely listening, speaking, reading and writing. Even more so, through the various assessment methods implemented, teachers could ensure students' learning objectives were achieved. Overall, the findings suggest that implementation of classroom-based assessment can enhance Arabic language teaching and learning especially in terms of changing teachers' attitudes, knowledge acquisition and skills in student assessment.
\end{abstract}

\section{Keywords}

Classroom-Based Assessment, Four Language Skills, Arabic, Lower Secondary

\section{Introduction}

The implementation of classroom-based assessment in the Secondary School 
Standard Curriculum (KSSM) enables the continuous process of assessment in teaching and learning in order to increase student achievement and strengthen teacher pedagogy. Proper implementation of classroom-based assessment will contribute to a more stimulating and conducive learning environment; furthermore, classroom-based assessment is an authentic assessment technique which doesn't pressure students' emotions (MOE, 2018).

In 2016, school assessments (PS) that were a major component of the school-based assessments (PBS) in the academic category were changed to classroom-based assessments (PBD). To make these classroom-based assessments successful, the role of teachers is crucial in determining the learning objectives to be assessed, designing and building assessment tools and carrying out the assessments.

\section{Problem Statement}

The Ministry of Education (MOE) (2018) has introduced Arabic language to schools under the MOE since even the 1970's. However, past researchers have stated that the subject of Arabic language is often considered difficult to learn and students are also less capable of speaking (in Arabic) during school situations (Jefridin, 2011). Past researches on classroom-based assessment reported that there are still some teachers who are only knowledgeable on the assessment method but are not proficient in their implementation. Whereas the role of teachers in the classroom is comprehensive, and so they need to be proficient in a variety of ways to assess their students, whether assessing on their activities or their work (Yusoff, 2013; Ramli, 2016).

In addition, if misinformation or lack of complete information on school assessments were to happen, it will lead to an unfair attitude towards assessing students (Sidek \& Salleh, 2012; Abdullah et al., 2015). Furthermore, Brookhart (1997) found that the implementation of classroom-based assessments conducted by teachers who are less knowledgeable about assessment concepts will have a negative impact on student learning.

At the same time, past research has shown that teachers who fail to properly manage school assessments' evidences will make assessment activities seem like its merely routine (Abdullah, 2017). Next, the examination factor caused teachers to rush in finishing the syllabus and hence resulted in assessment activities such as drilling of language skills to be stalled (Habibah, 2016).

Based on this problem statement, then research on the implementation of classroom-based assessment in the context of lower secondary Arabic should be researched considering that there are still holes in past researches from the aspect of the implementation of classroom-based assessment especially for four key language skills which are listening, speaking, reading and writing.

\section{Research Objective}

The main objective of this study is to explore the implementation of class- 
room-based assessment in effort to improve the process of teaching and learning Arabic language at the lower secondary level.

\section{Research Question}

This study is designed to answer the question "How can implementing classroom-based assessment improve the process of teaching and learning Arabic language at the lower secondary level?"

\section{Research Concept}

The word assessment comes from the Latin word assidere which means to sit next to (Satterly, 1989), that is to be next to the student, to be in close contact with the student, to share experiences with the student and to assist the student. Therefore, assessment is a process of gathering and interpreting information about students in making decisions that will help in improving the teaching and learning process (Nordin, 2010). Continuous assessment refers to a system of quality assessment of student work at each level of the course.

The implementation of classroom-based assessment is to improve student learning through formative assessment, namely assessment for learning and assessment as learning. Even with the implementation of classroom-based assessment, it is also possible to measure the level of student progress after a certain period of time through a summative assessment that is considered assessment of learning (MOE, 2018).

In order to measure the level of student mastery in the classroom-based assessment system, it is expressed in the form of performance standards as specified in the Curriculum and Assessment Standard Document (DSKP). In addition to reference to performance standards, teachers must also first refer to content standards and learning standards in effort to implement classroom-based assessment at the secondary level (MOE, 2018).

\section{Research Methodology}

This study uses a qualitative approach, and a case study method was selected to study the experience of real cases (Stake, 2006) and to collect detailed data (Creswell, 2005) to explore the implementation of classroom-based assessment in effort to improve the teaching and learning process of lower secondary Arabic language.

In order to make the study phenomenon more meaningful, the study was conducted in three schools offering lower secondary Arabic language subjects. The study participants were selected using purposive sampling (Merriam, 2009) based on the assumption that the study participants were Arabic language teachers rich in classroom-based assessment information and could help answer the research question. Two data collection techniques were used: interview and document review. Interview is the basic method in case study (Merriam, 1998; Chua, 2011; Jasmi, 2010) and subsequently added proof through 
document review (Gay, 1996). According to Konting (2005), the interview method is very practical to obtain accurate information from a small number of informants.

Once the transcription results have been validated, the researcher compiled and administered the data to get the categories and themes with the help of the Nvivo 12 software. The findings of the study are comprehensive, holistic and descriptive (Lebar, 2012), but not generalized.

\section{Research Findings}

\subsection{Classroom-Based Assessment Is a Holistic Assessment}

The implementation of classroom-based assessment holistically encompasses four major aspects of Arabic language skills: listening, speaking, reading and writing. The implementation of classroom-based assessment will provide comprehensive information on student development of these four language skills. Here are some excerpts from interviews that depict classroom-based assessment (PBD) as holistic.

"This classroom-based assessment emphasizes maharatul istima', maharatul kalam, maharul kitabah kan ... maharah qiraah" TBGBA1.

"Then the emphasis on classroom-based assessment starts with the istima', then it goes to kalam, then it goes to qiraah and finally to kitabah" TBGBA2.

"Skills are emphasized in classroom-based assessment, which are listening skills, speaking skills, reading skills and writing skills ... we are focused Directly" TBGBA3.

The statements clearly prove that Arabic classroom-based assessment was implemented upon four key language skills like listening, speaking, reading and writing.

\subsection{Classroom-Based Assessment Is a Continuous Assessment}

The implementation of classroom-based assessment in Arabic subjects emphasizes $t$ The implementation of classroom-based assessment is also carried out continuously throughout the classroom teaching and learning. In other words, classroom-based assessment is carried out throughout the year. The following are statements from study participants describing classroom-based assessment (PBD) conducted continuously during the proces of teaching and learning.

"Later I have informed the kids. When I left ... an oral briefing in Arabic. I said speaking in Arabic ... it will happen in the teaching and learning" TBGBA1.

"I'm based on the classroom-based assessment that I made during the course of learning" TBGBA2

"It's all ready ... it's easy ... because we do it during learning" TBGBA3.

Based on the above statements, it is proved clearly that classroom-based assessments were done by teachers during classroom teaching and were done continuously throughout the year. 


\subsection{Implementation of Classroom-Based Assessment That Emphasize the Acquisition of Four Language Skills}

The implementation of classroom-based assessment in Arabic subjects emphasizes the mastery of the four main language skills, namely, listening, speaking, reading, and writing based on the stages of mastery. At the same time speaking skills are highly emphasized. This statement was also confirmed by all interviewers.

"Students do the listening exercises and students also practice writing ... I will check their exercises, writing exercises, even with that we can implement classroom-based assessment" TBGBA1.

"The KSSM (Secondary School Standard Curriculum) has helped me, there are so many positives, in terms of students' speaking skills, they now have vocabulary" TBGBA2.

"In order to attain level 6 (in the performance level) one has to be consistent ... that means ... if he does it ... say if he can already speak ... he must always be right, no mistake" TBGBA3.

The statements clearly prove that the process of teaching, learning and assessing upon students prioritized the four key language skills in Arabic. What more, the ability to speak (in Arabic) amongst students is prioritized.

\subsection{Implementation of Classroom-Based Assessment Makes Teacher More Aware and Familiar of Their Students}

Implementing classroom-based assessment makes Arabic language teachers more aware and familiar of their students covering all aspects such as student achievement, interest and attitude throughout the teaching and learning process. This allows teachers to monitor student progress more quickly and indirectly. This is evidenced by the following statement.

"That class we know ... well" TBGBA1.

"The student that I taught, there is an improvement ... there is always an improvement" TBGBA2.

The statements clearly reinforce that classroom-based assessments make it easier for teachers to know their students based on the factor that they would always need to make observations, give assessments and assign them their performance levels.

\subsection{Implementation of Classroom-Based Assessment Stimulate Teachers and Students to Be Skilful in Assessment}

The implementation of PBD calls for a change in the attitude of teachers and students to embrace innovation and demand positive perception for effective implementation of classroom-based assessment. Through classroom-based assessment, teachers and students are informed that they will be more skilled and trained in assessment practices especially in setting the level for students. This is evidenced by the following statement. 
"We give him maybe a performance level of 2, then he'll go up, up, up ... and then finally he will go to the right level of mastery" TBGBA1.

"If there is a student who doesn't want to answer, I call him to answer it too ... as to decide his performance level" TBGBA2.

"Back then it was difficult if we wanted to know the achievements of our students ... now we know it quickly" TBGBA3.

The statements clearly show that teachers were more ready and creative in giving students assessments and assigning them their performance levels: Insert one hard return immediately after the last character of the last affiliation line. Then paste down the copy of affiliation 1 . Repeat as necessary for each additional affiliation.

\subsection{Implementation of Classroom-Based Assessment Is Adjusted to the Level of Students' Development}

The study participants stated that each student had varying levels of mastery. This requires teachers to plan assessments taking into account student's level of mastery. This statement is consistent with the following statement.

"With us already planning his intervention, we do the intervention with him ... how long (duration) we think he'll take. Ha ... that's one of it right" TBGBA1.

"The DSKP (Standard Document) teachers do it based on that, based on their students. It can't be the same" TBGBA2.

"Aha ... maybe he can't reach that level, level 6. So, at this point, because he's more of an example" TBGBA3.

The statements clearly prove that the implementation of classroom-based assessments needs to be adjusted according to the students' levels of performance which are not the same in the classroom

\section{Discussion and Summary}

Implementing classroom-based assessment enables teachers to monitor students' overall development and to recognize students' mastery of the four key Arabic language skills such as listening, speaking, reading and writing (Ismail, 2008; Mahamod, 2010). The research finding proving that teachers know more on their students is in line with the statement of Hamimah \& Rohaya (2014) who stated that implementing school assessments makes teachers more concerned towards students' development in various aspects. This enables teachers to constantly observe and get to know their students. Teachers can also provide feedback faster to help students follow the next lesson. All forms of student weakness can be identified early on and will provide advice and guidance on improving student achievement.

Findings which proved that implementing classroom-based assessment to enable teacher observation throughout the classroom are also supported by $\mathrm{Ru}$ hila Adnan's (2012) statement that school assessment is a formative assessment that is ongoing and teachers do not have to wait for exams to measure student 
achievement. Further, the finding of this classroom-based assessment research which proves teachers are skilled in carrying out assessments is in line with the statements of Murugaya (2010) and Hamimah \& Rohaya (2014) which also stated that school assessments encourage students to be actively involved and enable students to provide the best work to attain teachers' attention. Accordingly, the findings of the study clearly show that classroom-based assessment is indeed holistic and continuous in line with the opinions of Black \& William (1998) and Hussain (2012) which stated that efforts should always focus on formative assessment in order for the assessment to be done holistically and consistently on students throughout the teaching and learning process.

Accordingly, the findings of the study clearly show that these holistic and continuous classroom-based assessments are in line with Black \& William's (1998) opinion that efforts are made to focus on formative assessments in order to enable comprehensive and ongoing assessment of students.

Overall, the findings show that classroom-based assessments can be implemented more effectively if teachers are given training or courses related to assessors and implementing classroom-based assessments at school level. It is hoped that through the implementation of effective classroom-based assessments, it will raise the performance level of students in the four key Arabic language skills and at the same time enhance the process of teaching and learning in the classroom.

\section{Acknowledgements}

This research was supported by the Faculty of Education, Universiti Kebangsaan Malaysia code GG-2019-019 and PP-FPEND-2019.

\section{Conflicts of Interest}

The authors declare no conflicts of interest regarding the publication of this paper.

\section{References}

Abdullah, N., Noh, N. M., Mansor, R., Hashim, A. T. M., \& Teck, W. K. (2015). Penilaian Pelaksanaan Pentaksiran Berasaskan Sekolah (PBS) Dalam Kalangan Guru Sains. Jurnal Pendidikan Sains \& Matematik, 5, 90-102.

Abdullah, W. M. Z. W. (2017). Eviden Pentaksiran Sekolah Dalam Pengajaran Bahasa Arab Sekolah Rendah. Tesis PhD, Kuala Lumpur: Fakulti Pendidikan Universiti Malaya.

Adnan, R. (2012). Perkaitan Antara Kefahaman Guru Dan Kesediaan Guru Matematik Terhadap Pelaksanaan Pentaksiran Berasaskan Sekolah (PBS) Di Daerah Pasir Gudang, Johor. Laporan Projek Sarjana Pendidikan. Skudai: Fakulti Pendidikan Universti Teknologi Malaysia.

Black, P., \& William, D. (1998). Assessment and Classroom Learning. Assessment in Education, Principles, Policy and Practice, 5, 7-73.

https://doi.org/10.1080/0969595980050102 
Brookhart, S. M. (1997). A Theoretical Framework for the Role of Classroom Assessment in Motivating Student Effort and Achievement. Applied Measurement in Education, 10, 161-180. https://doi.org/10.1207/s15324818ame1002 4

Chua, Y. P. (2011). Kaedah penyelidikan. Kuala Lumpur: McGraw Hill Education.

Creswell (2005). Educational Research: Planning, Conducting and Evaluating Quantitative and Qualitative Research. Upper Saddle River, NJ: Merill Prentice Hall.

Gay, L. R. (1996). Education Research: Competencies for Analysis and Application. Edisi ke-5. Upper Saddle River, NJ: Prentice Hall, Inc.

Habibah, M. R. (2016). Amalan Pentaksiran Dalam Pengajaran Dan Pembelajaran Insya' Sijil Tinggi Agama Malaysia (STAM). Tesis PhD, Kuala Lumpur: Fakulti Pendidikan, Universiti Malaya.

Hamimah, A. N., \& Rohaya, T. (2014). Cabaran Pentaksiran Berasaskan Sekolah (PBS): Delima Guru. In Prosiding Persidangan Antarabangsa Kelestarian Insan 2014 (pp. 230-242). Batu Pahat: Universiti Tun Hussin Onn (UITHO).

Hussain, S. H. Z. S. (2012). Amalan penilaian formatif dalam kalangan guru-guru di Sekolah Menengah Arab di Negara Brunei Darusslam. Tesis Sarjana Pendidikan, Bangi: Fakulti Pendidikan, Universiti Kebangsaan Malaysia.

Ismail, Z. (2008). Penilaian Kemahiran Bertutur Bahasa Arab Dalam Kurikulum Bahasa Arab Komunikasi Di Sekolah Menengah Kebangsaan Agama. Tesis PhD, Bangi: Fakulti Pendidikan, Universiti Kebangsaan Malaysia.

Jasmi, K. A. (2010). Guru Cemerlang Pendidikan Islam Sekolah Menengah Di Malaysia: Satu Kajian Kes. Tesis PhD, Bangi: Fakulti Pendidikan, Universiti Kebangsaan Malaysia.

Jefridin, P. (2011). Maklum Balas Guru Terhadap Respon Pelajar Semasa Pengajaran Bahasa Arab Tinggi: Satu kajian kes. Tesis PhD, Bangi: Fakulti Pendidikan UKM.

Konting, M. M. (2005). Kaedah Penyelidikan Pendidikan. Edisi ke-5. Kuala Lumpur: Dewan Bahasa \& Pustaka.

Lebar, O. (2012). Penyelidikan Kualitatif: Pengenalan Kepada Teori Dan Method. Tanjung Malim: Penerbitan Universiti Pendidikan Sultan Idris.

Mahamod, Z., Embi, M. A., \& Yusoff, N. M. R. N. (2010). Pentaksiran Berasaskan Sekolah (PBS), Panduan Untuk Guru Bahasa Melayu, Inggeris Dan Arab. Fakulti Pendidikan, Bangi: Universiti Kebangsaan Malaysia.

Merriam, S. B. (1998). Case Study Research in Education. A Qualitative Approach. San Francisco, CA: Jossey-Bass Publishers.

Ministry of Education (MOE) (2018). Panduan Pelaksanaan Pentaksiran Bilik Darjah. Bahagian Pembangunan Kurikulum, KPM Putrajaya.

Nordin, M. S. (2010). Pengujian Dan Penaksiran Di Bilik Darjah. Kuala Lumpur: Pusat Penyelidikan Universiti Islam Antarabangsa Malaysia (UIAM).

Ramli, S. A. M. (2016). Kesediaan dan Keprihatinan Guru Pendidikan Islam Terhadap Pelaksanaan Pentaksiran Berasaskan Sekolah. Tesis Sarjana Fakulti Pendidikan, Bangi: Universiti Kebangsaan Malaysia.

Satterly, D. (1989). Assessment in School(2nd ed.). Oxford: Basil Blackwell.

Sidek, R. Z. S. b., \& Salleh, S. F. bt M. (2012). Kesediaan Guru Sekolah Menengah di Daerah Kota Baharu Dalam Melaksanakan Sistem Penilaian Prestasi Pelajar Berasaskan Sekolah. Skudai: Fakulti Pendidikan, Universiti Teknologi Malaysia.

Stake, R. E. (2006). Multiple Case Study Analysis. New York: The Guilford Press. 
TBGBA1, Temu bual Guru Bahasa Arab 1.

TBGBA2, Temu bual Guru Bahasa Arab 2.

TBGBA3, Temu bual Guru Bahasa Arab 3.

Yusoff, T. A. T. (2013). Kesediaan Guru Melaksanakan Pentaksiran Berasaskan Sekolah. Kertas Projek Sarjana, Bangi: Fakulti Pendidikan, Universiti Kebangsaan Malaysia. 